\title{
INDUCTION OF RESISTANCE IN PHASEOLUS VULGARISTO ROOT ROT DISEASE, CAUSED BY RHIZOCTONIA SOLANI, USING JASMONIC ACID
}

\author{
HATHOUT, TAHANI A. ${ }^{1}$, M. S. FELAIFEL ${ }^{2}$, SAMIA M. EL-KHALLAL ${ }^{1}$, \\ HODA H. ABO-GHALIA ${ }^{1}$ AND RABAB A.GAD ${ }^{1}$
}

1. Botany Department, University College of Women for Art, Science and Education.Ain Shams University, Cairo

2. Plant Pathology Research Institute, $A R C$, Giza

(Manuscript received 12 November 2009)

\begin{abstract}
Application of $10 \mu \mathrm{M}$ of Jasmonic acid (IA) as seed soaking significantly reduced $\%$ of root rot incidence in bean plants. Production of reactive oxygen species especially $\mathrm{H}_{2} \mathrm{O}_{2}$ was highly increased in both roots and shoots of $R$. solani infected-plants, as compared with non-infected control. JA significantly decreased the level of $\mathrm{H}_{2} \mathrm{O}_{2}$ in roots of 14 and 28 days old plants. Lipid peroxidation decreased in JA-treated plants, as compared with infected control. Activity of antioxidant enzymes (catalase, ascorbate peroxidase and superoxide dismutase) significantly increased in bean tissues in response to both pathogenic fungi (R.solani) and/or elicitor JA. JA-treated plants significantly increased total phenolic compounds and various phenolic acids except gallic acid in bean roots as compared with infected or noninfected control. Coumarin was induced only by JA. Additionally, activities of POX, PPO and PAL were greatly increased in both roots and shoots of bean plants infected by Rhizoctonia solani. JA treated plants showed the highest enzymes activity.

Key words: Jasmonic acid - Rhizoctonia solani - Phaseolus vulgaris - antioxidants - phenolic compounds
\end{abstract}

\section{INTRODUCTION}

Bean (Phaseolus vulgaris) is considered one of the major leguminous crops in Egypt. Root rot and Alternaria leaf spot diseases caused by Fusarium solani, Rhizoctonia solani and Alternaria alternata, respectively, are serious and persistent disease problems of bean plant during growing season (Abd El-Kareem, 2007).

Several strategies for controlling bean soil-borne diseases have been introduced, such as soil fumigation and use of chemical pesticides (fungicides). However, the development of fungicide resistance by pathogens and increasing environmental concern of fungicidal residues in fruit and vegetables has stimulated the search for alternative measures for disease control.

Plant treatment with appropriate biotic and abiotic agents can induce resistance to pathogen attack including fungi, viruses and bacteria. The induced state can be achieved by increasing the production of a range of defense-related 
products such as defense-induced signaling compounds, pathogenesis-related proteins, (PRP) and phytoalexins. The induced resistance (IR) phenomena are often associated with an enhanced capacity to mobilize cellular defense responses against pathogen attack. Induced resistance in plants can be subdivided into broad categories. The pathogen-induced resistance has been termed systemic acquired resistance (SAR) controlled by a signaling pathway that depends on endogenous accumulation of salicylic acid (SA) which associated with the accumulation of defense compounds, such as PR proteins. Other kinds of JA-dependant response is the so-called induced systemic resistance (ISR), which is produced when the roots are colonized by certain non pathogenic rhizobacteria and arbuscular mycorrhizal fungus (Pieterse and Van Loon, 1999).

Jasmonic acid (JA) and its methyl derivatives (MeJA) represent a class of plant growth regulators that plays pervasive roles in several aspects of plant development. Recent molecular genetic studies have confirmed the involvement of JA in both developmental and defense-related processes (Halitschke and Baldwin 2005). The biosynthesis of JA is regularly adjusted in plant tissues and its subject to induce control by various elicitors including wounding and pathogens. The signal molecule JA, when exogenously applied has been shown to move systemically through plants resulting in the expression of a set of defense genes that are activated by pathogen infection. For example, in sweet basil, the total phenolic content increased significantly after plants were treated with MeJA (Kim et al. 2006). MeJA treatment increased the production of terpenoid indole alkaloids in Catharanthus and Cinchona and enhanced the production of these secondary metabolites in the treated tissues of tomato (Chen et al., 2006).

In the present work, JA was used to enhance defense mechanisms in Phaseolus vulgaris against root rot disease caused by Rhizoctonia solani. Thus, oxidizing enzyme activities, active oxygen species levels and phenolic compounds were investigated in roots and shoots of bean plants.

\section{MATERIALS AND METHODS}

Bean seeds (Phaseolus vulgaris cv. Proncho), were surface sterilized for $1 \mathrm{~min}$ in $75 \%$ ethanol, immersing for $3 \mathrm{~min}$ in sterile distilled water, and then left to dry overnight. Sterilized seeds were grown in large pots $(30-\mathrm{cm}$ in diameter) containing sand loamy soil $(2: 1 \mathrm{w} / \mathrm{w})$ under greenhouse conditions. The pots were divided into three groups (10 pots/group) and treated as the follows:

I. Soil of the $1^{\text {st }}$ group were left without any treatments (non-infected control). 
II. Soil of the $2^{\text {nd }}$ group were infected with the pathogenic fungus Rhizoctonia solani (infected control).

III. Seeds of ${ }^{3 r d}$ group were treated with $\mathrm{JA}(10 \mu \mathrm{M})$ as seed soaking for 8 hours + R.solani.

\section{Preparation of pathogen inoculum}

Inoculum of Rhizoctonia solani was prepared by growing the fungus on autoclaved corn sand meal medium supplemented with $0.2 \%$ peptone solution. Flasks containing the medium were inoculated with disks $(0.5 \mathrm{~cm})$ of three days old R.solani cultures and incubated at $20^{\circ} \mathrm{C}$ for 30 days.

\section{Soil infestation}

Inoculum of Rhizoctonia solani was added to soil at the rate of $3 \%$ of soil weight, one week before planting, to ensure its distribution in the soil.

\section{Plant Harvest and Analysis}

Plants were harvested at two stages (14 and 28 after planting). Shoots and roots were separated from plants and immediately frozen in liquid nitrogen until use for various biochemical analyses.

The percentage of disease incidence (PI) was assessed using the following formula according to (Yehia et al. 2007):

$$
\mathrm{PI}=\frac{\text { No. of infected plants } \times 100}{\text { Total No. seeds sown }}
$$

\section{Assay of hydrogen peroxide $\left(\mathrm{H}_{2} \mathrm{O}_{2}\right)$ and Lipid Peroxidation:}

Hydrogen peroxide levels were determined according to Velikova et al. (2000). Half $\mathrm{g}$ fresh wt. of bean tissue was homogenized in $2 \mathrm{ml}$ of $0.1 \%$ trichloroacetic acid (TCA) solution. After centrifugation at $12,000 \mathrm{~g}$ for $15 \mathrm{~min}, 0.5 \mathrm{ml}$ of the supernatant was added to the reaction mixture containing $0.5 \mathrm{ml}$ of $10 \mathrm{mM}$ potassium phosphate buffer ( $\mathrm{pH} \mathrm{7.0)}$ and $1 \mathrm{ml}$ of $1 \mathrm{M}$ potassium iodide (KI). Absorbance was determined at $390 \mathrm{~nm}$. The blank was prepared in the same manner except that $1 \mathrm{ml}$ of $10 \mathrm{mM}$ potassium phosphate buffer $(\mathrm{pH} 7.0)$ instead of the sample. The amount of $\mathrm{H}_{2} \mathrm{O}_{2}$ was calculated from calibrated samples using $\left(1,5,10 \mathrm{mM} \mathrm{H}_{2} \mathrm{O}_{2}\right)$ standard solutions, One half $\mathrm{ml}$ of each standard solution was added to the reaction mixture containing $0.5 \mathrm{ml}$ $10 \mathrm{mM}$ potassium phosphate buffer $(\mathrm{pH} 7.0)$ and $1 \mathrm{ml}$ of $1 \mathrm{M}$ potassium iodide. Absorbance was determined at $390 \mathrm{~nm}$.

Level of lipid peroxidation was measured as the amount of malondialdhyde (MDA), which reacts with thiobarbituric acid (TBA) to form TBA-MDA complex and measured at 532 and $600 \mathrm{~nm}$. Total MDA equivalent were calculated according to the following equation: 
Total MDA (nmo/g FW) =

Amount of extraction buffer $(\mathrm{ml}) \times$ amount of supernatant $(\mathrm{ml}) \times\left[(\right.$ Abs 532-Abs 600/ 155) $] \times 10^{3}$

Amount of sample (g)

\section{Extraction of oxidizing enzymes}

Extraction was made as reported by Silvana et al. (2003). One $\mathrm{g}$ fresh weight of plant tissue was homogenized in mortar with $10 \mathrm{ml}$ of a mixture containing $50 \mathrm{mM}$ phosphate buffer pH 7.4, 1 mM EDTA, 1 g polyvinylpyrrolidone (PVP) (Mol. wt 40,000) and $5 \%(\mathrm{v} / \mathrm{v})$ Triton $\mathrm{X}-100$ under cooling condition. The homogenate was centrifuged at $10000 / \mathrm{g}$ for $20 \mathrm{~min}$ in a prechilled mortar and pestle at $4^{\circ} \mathrm{C}$ and the supernatant was used for the assay of peroxidase (POX), catalase (CAT), ascorbate peroxidase(APOX) and superoxide dismutase (SOD).

\section{Assay of Peroxidase Activity (POX)}

Peroxidase activity was determined following the method of Jiang et al. (1984). POX activity was measured in a reaction mixture consisting of supernatant $(1 \mathrm{ml})$ and guaiacol substrate (Three $\mathrm{ml}$ of reaction mixture consisting of $100 \mathrm{mM}$ sodium phosphate buffer, pH 7.0, and $20 \mathrm{mM}$ guaiacol). The increase in absorbance at 470 $\mathrm{nm}$ was measured spectrophotometrically after $20 \mu \mathrm{L} \mathrm{H}_{2} \mathrm{O}_{2}$ was added. The enzyme activity was expressed as the change in optical density/ gram fresh weight/ min.

\section{Assay of Catalase Activity (CAT)}

The catalase activity was determined by recording the consumption of $\mathrm{H}_{2} \mathrm{O}_{2}$ at $240 \mathrm{~nm}$ for $30 \mathrm{sec}$ in $3 \mathrm{ml}$ of reaction mixture containing $100 \mathrm{mM} \mathrm{K}$.phosphate buffer pH 7.0, $20 \mu \mathrm{L}$ of $30 \% \mathrm{H}_{2} \mathrm{O}_{2}$ and $30 \mu \mathrm{L}$ enzyme extract (Aebi, 1995).

\section{Assay of Superoxide dismutase (SOD)}

The activity of total superoxide dimutase was determined according to Silvana et al. (2003). The activity was assayed by the inhibition of the photochemical reduction of nitroblue tetrazolium (NBT) $200 \mu \mathrm{l}$ of enzyme supernatant and $300 \mu$ buffer solution ( $50 \mathrm{~m} \mathrm{M} \mathrm{K-} \mathrm{phosphate} \mathrm{buffer} \mathrm{pH} 7.8$ and $0.1 \mathrm{~m} \mathrm{M} \mathrm{EDTA}$ ) were added to $3.5 \mathrm{ml}$ of $\mathrm{O}^{-2}$ generator mixture (14.3 mM methionine, $82.5 \mu \mathrm{M} \mathrm{NBT}$ and $2.2 \mu \mathrm{M}$ riboflavin). Test tubes were shaken and placed under florescent lamp for $10 \mathrm{~min}$. Reading were carried out at wave length $560 \mathrm{~nm}$. Blanks and controls were run in the same way but without illumination and enzyme, respectively. Superoxide dismutase activity unit defined as $\mathrm{mg}$ protein required to cause $50 \%$ inhibition of the reduction of Nitroblue Tetrazolium (NBT) at $560 \mathrm{~nm}$ under the assay conditions. 


\section{Assay of Ascorbate Peroxidase (APOX)}

Ascorbate peroxidase (APOX) activity was determined according to the method described by Rao et al. (1996). APOX activity was recorded by following the decrease in A 290 for $3 \mathrm{~min}$ in $1 \mathrm{ml}$ of reaction mixture containing $100 \mathrm{mM}$ phosphate buffer $\mathrm{pH}$ 7.5, $0.5 \mathrm{mM}$ ascorbate and $0.2 \mathrm{H}_{2} \mathrm{O}_{2} \mathrm{mM}$ and $30 \mu \mathrm{L}$ enzyme extract. Enzyme activity was expressed as mmol oxidized ascorbate $\mathrm{min}^{-1} \mathrm{gm}^{-1} \mathrm{~F}$.wt.

\section{Extraction of polyphenol oxidase and phenylalanine ammonia lyase}

Extraction of PPO and PAL were done as reported by Yingsanga et al. (2008). Powdered samples ( $0.5 \mathrm{~g}$ ) was homogenized with buffer containing $20 \mathrm{ml}$ of $100 \mathrm{mM}$ sodium phosphate buffer ( $\mathrm{pH} 7.0$ ) and $0.5 \mathrm{~g}$ polyvinyl pyrrolidone (PVP) for the assay of the activities of PPO. PAL activity was measured in powders extracted with $50 \mathrm{mM}$ sodium phosphate buffer ( $\mathrm{pH} 8.8$ ) containing $5 \mathrm{mM} \beta$-mercaptoethanol. The extracts were filtered through two layers of miracloth and the filtrates were centrifuged at $27,000 \mathrm{~g}$ at $4^{\circ} \mathrm{C}$ for $30 \mathrm{~min}$.

\section{Assay of polyphenol oxidase (PPO)}

PPO activity was assayed as described by Luh and Phithakpol (1972). One $\mathrm{ml}$ of supernatant was mixed with $1 \mathrm{ml}$ of sodium phosphate buffer (100 mM, pH 7.0) and 1 $\mathrm{ml}$ pyrocatechol $(50 \mathrm{mM})$. Changes in absorbance at $410 \mathrm{~nm}$ were measured spectrophotometrically. One unit of PPO activity was defined as a change in optical density gm fresh $\mathrm{wt}^{-1} \mathrm{~min}^{-1}$.

\section{Assay of Phenylalanine ammonia lyase (PAL)}

PAL activity was measured following the method of Ross and Sederoff (1992) the reaction mixture, containing $100 \mu \mathrm{l}$ of plant extract, $500 \mu \mathrm{l}$ of $50 \mathrm{mM}$ Tris $\mathrm{HCI}(\mathrm{pH}$ 8.8), and $600 \mu \mathrm{l}$ of $1 \mathrm{mM} \mathrm{L-}$ Phenylalanine, was incubated for $60 \mathrm{~min}$ at room temperature, and reaction was stopped by adding $2 \mathrm{~N} \mathrm{HCI}$. The assay mix was extracted with $1.5 \mathrm{ml}$ of toluene by vortexing for $30 \mathrm{sec}$. Toluene was recovered after centrifugation at $1000 \mathrm{rpm}$ (CRU-5000 centrifuge ITC) for $5 \mathrm{~min}$. The absorbance of the toluene phase containing trans- cinnamic acid was measured at $290 \mathrm{~nm}$ against the blank of toluene. Enzyme activity was expressed as nmol trans- cinnamic acid released $\mathrm{min}^{-1} \mathrm{~g}^{-1}$ fresh weight

\section{Extraction and analysis of phenolic compounds}

Frozen tissue $(1 \mathrm{~g})$ was homogenized with $10 \mathrm{ml}$ of $80 \%$ methanol and the extract left for $24 \mathrm{~h}$ at room temperature before centrifugation at $15,000 \mathrm{~g}$ for $10 \mathrm{~min}$. (Swain and Hillis, 1959). One $\mathrm{ml}$ of the methanolic extract was added to $5 \mathrm{ml}$ of distilled water and $250 \mu \mathrm{L}$ of Folin-ciocalteau reagent, and the solution was kept at 25 ${ }^{\circ} \mathrm{C}$ for $30 \mathrm{~min}$, then $1 \mathrm{ml}$ of a saturated solution of $\mathrm{Na}_{2} \mathrm{CO}_{3}$ and $1 \mathrm{ml}$ of distilled water were added, and the mixture was incubated for $1 \mathrm{~h}$ at $25{ }^{\circ} \mathrm{C}$. The absorption of the 
developed blue colour was measured using spectrophotometer at $725 \mathrm{~nm}$. The total phenolic content was calculated by comparison with a standard curve obtained from a folin reaction with phenol. On the other hand, various phenolic acids in bean roots and shoots were determined using HPLC. Phenolic acids present in the samples were identified by comparing retention time (RT) of standard. Concentrations were calculated by comparing peak areas of different compounds with those in the samples under the same elution condition.

\section{Statistical Analysis}

The obtained data were statistically analysed using the one way analysis of variance as described by Snedecor and Cochran (1969). The means were compared by L.S.D. using Statistical Package for Social Sciences (SPSS) program version 12.

\section{RESULTS AND DISCUSSION}

Data in table (1) indicated that application of jasmonic acid as seed presowing elicitor greatly reduced \% of root rot incidence of bean plants as compared with infected control. However, \% incidence infected plants in healthy control could be attributed to a low level of natural contamination with the pathogen in the used soil. Plants respond to pathogen attack or elicitor treatment by activation a wide variety of protective mechanisms designed to prevent pathogen replication and spreading. Josmonic and soliaylic acids (hormonal elicitor) are major regulators of plant response to pathogen attack (Segarra et al., 2006).

Table 1. Reduction of root rot (\%) caused by $R$. solani in bean plants treated with jasmonic acid (JA) after 14 days from sowing.

\begin{tabular}{|l|c|}
\hline Treatment & Disease incidence (\%) \\
\hline Control (non-treated) & $13.00^{\mathrm{c}} \pm 2.3$ \\
\hline R.solani & $44.82^{\mathrm{a}} \pm 5.2$ \\
\hline R.solani + JA & $24.50^{\mathrm{b}} \pm 3.8$ \\
\hline LSD at 5 \% & 4.55 \\
\hline
\end{tabular}

Means within the same column with the same letter not significantly different $(P \leq 5 \%)$

The disease incidence was reduced from $44.82 \%$ in infected control to $24.50 \%$ in JA treatment. Our results are in harmony with those by Segarra et al. (2006). 


\section{Changes in Hydrogen Peroxide $\left(\mathrm{H}_{2} \mathrm{O}_{2}\right)$ and Lipid Peroxidation}

One of the earliest responses of plants to microbial pathogens is the production of reactive oxygen species (ROS) such as superoxide and hydrogen peroxide $\left(\mathrm{H}_{2} \mathrm{O}_{2}\right)$. The role of ROS during hypersensitive response (HR) has been better defined and evidence has come to light on a novel function for $\mathrm{H}_{2} \mathrm{O}_{2}$ in disease resistance, namely as a second messenger for systemic acquired resistance (SAR) and also to play a role in defense response against a biotic stress (Shimizu et al., 2006).

The production of reactive oxygen species (ROS) is one of the earliest cellular responses following successful pathogen recognition. Results in Table (2) showed that infection by Rhizoctonia solani significantly increased levels of $\mathrm{H}_{2} \mathrm{O}_{2}$ in roots and shoots of bean plants compared with non infected control, and these levels increased with time progress. High levels of ROS may be directly involved in pathogen inhibition and strengthening of plant cell walls, as well as triggering hypersensitive cell death (HR) (Huckelhoven and Kogel, 2003) and in production of systemic resistance signaling.

Application of hormonal elicitors such as JA markedly decreased levels of $\mathrm{H}_{2} \mathrm{O}_{2}$ in roots and increased it in shoots of bean seedlings as compared with infected control, and its level decreased with increasing the time (Table 2). JA induced $\mathrm{H}_{2} \mathrm{O}_{2}$ production in pepper (Ueeda et al., 2006), which triggers expression of plant resistance and HR-related genes in the whole plant. It was found that exogenous elicitor and pathogen could trigger local $\mathrm{H}_{2} \mathrm{O}_{2}$ burst which induced the systemic acquired resistance.

Table 2. Levels of hydrogen peroxide $\left(\mathrm{H}_{2} \mathrm{O}_{2}\right)$ and malondialdehyde (MDA) in roots and shoots of bean plants infected by R.solani and treated with jasmonic acid (JA).

\begin{tabular}{|c|c|c|c|c|c|c|c|c|}
\hline \multirow{2}{*}{$\begin{array}{c}\text { Treatment } \\
\text { Days after }\end{array}$} & \multicolumn{4}{|c|}{$\mathrm{H}_{2} \mathrm{O}_{2}$ ( $\mu \mathrm{mol} \mathrm{g}{ }^{-1}$ f.wt.) } & \multicolumn{4}{|c|}{ MDA(n mol g ${ }^{-1}$ f.wt.) } \\
\hline & \multicolumn{2}{|c|}{ Root } & \multicolumn{2}{|c|}{ Shoot } & \multicolumn{2}{|c|}{ Root } & \multicolumn{2}{|c|}{ Shoot } \\
\hline $\begin{array}{l}\text { Days after } \\
\text { planting }\end{array}$ & 14 & 28 & 14 & 28 & 14 & 28 & 14 & 28 \\
\hline control & $0.22^{\mathrm{c}}$ & $0.35^{\mathrm{b}}$ & $0.42^{\mathrm{c}}$ & $0.56^{\mathrm{b}}$ & $8.22^{c}$ & $4.46^{\mathrm{b}}$ & $11.91^{\mathrm{b}}$ & $12.70^{c}$ \\
\hline R.solani & $0.63^{\mathrm{a}}$ & $0.81^{\mathrm{a}}$ & $0.83^{\mathrm{b}}$ & $1.05^{\mathrm{a}}$ & $10.19^{a}$ & $10.73^{\mathrm{a}}$ & $14.73^{\mathrm{a}}$ & $15.85^{\mathrm{a}}$ \\
\hline R.solanis + JA & $0.55^{b}$ & $0.50^{c}$ & $1.28^{\mathrm{a}}$ & $1.14^{\mathrm{a}}$ & $9.20^{\mathrm{b}}$ & $10.02^{\mathrm{a}}$ & $13.81^{\mathrm{a}}$ & $14.32^{\mathrm{b}}$ \\
\hline LSD at $5 \%$ & 0.04 & 0.09 & 0.21 & 0.14 & 0.87 & 1.59 & 1.20 & 1.38 \\
\hline
\end{tabular}

Means within the same column with the same letter are not significantly different $(P \leq 5 \%)$ 
Measurement of malondialdhyde (MDA) levels is routinely used as an index of lipid peroxidation under stress conditions. MDA levels gradually increased in roots and shoots of infected bean plant with increasing time. In infected plant treated with hormonal elicitor JA, MDA level markedly decreased as compared with infected control. Thus, JA has a benefit to prevent membrane damage during infection may be through membrane stabilization and/or reduction of reactive oxygen species $\left(\mathrm{H}_{2} \mathrm{O}_{2}\right.$, $\left.\mathrm{OH}, \mathrm{O}_{2}, \ldots ..\right)$. When higher plants are subjected to a pathogen, the equilibrium between productions and scavenging of ROS is broken, resulting in oxidative damage of proteins, DNA and lipids. MDA is one of the byproducts and could reflect the degree of peroxidation of membrane lipid.

Higher levels of $\mathrm{H}_{2} \mathrm{O}_{2}$ may have a role in causing limited necrotic lesions (HR-like lesions). Lipid peroxidation, which coincided with $\mathrm{H}_{2} \mathrm{O}_{2}$ accumulation in two date palm cultivars studied by Jaiti et al. (2004) indicated that treatment of seedlings of date palm with jasmonic acid enhanced lipid peroxidation as indicated by MDA accumulation.

\section{Changes in the Activity of Antioxidation Enzymes}

Results in Table (3) showed that bean infected with Rhizoctonia solani significantly showed increased SOD, POX, CAT and APOX in both roots and shoots as compared with non-infected control. ROS could be constitutively generated in the healthy plant cells, but excessive ROS would poison or kill the cells. Meanwhile, many previous researches had demonstrated that some mechanisms in plant cells had accordingly evolved to scavenge ROS. Several important antioxidant enzymes including SOD catalyses the dismutation of $\mathrm{O}^{-2}$ to $\mathrm{H}_{2} \mathrm{O}_{2}$, CAT dismutates $\mathrm{H}_{2} \mathrm{O}_{2}$ to oxygen and water, and POX, ascorbate peroxidase (APOX) reduces $\mathrm{H}_{2} \mathrm{O}_{2}$ to water by ascorbate ASC as specific electron donor.

Treatment with JA raised the activities of the antioxidant enzymes. The increases in CAT and APOX observed in our experiments may be related to their antioxidation role against any active oxygen molecules generated during the initial stage of fungus penetration. 
Table 3. Superoxide dismutase (SOD), catalase (CAT) and ascorbate peroxidase (APOX) activities of shoots and roots of bean plants infected with Rhizoctonia solani (R.solani) and treated with JA.

\begin{tabular}{|c|c|c|c|c|c|c|c|c|c|c|c|c|}
\hline \multirow{2}{*}{$\begin{array}{c}\text { Treatment } \\
\text { Days after }\end{array}$} & \multicolumn{4}{|c|}{ SOD (U g fresh wt.) } & \multicolumn{4}{|c|}{ CAT ( $\mu \mathrm{mol} \mathrm{H} \mathrm{H}_{2} \mathrm{~min}^{-1} \mathrm{~g}^{-1}$ fresh wt.) } & \multicolumn{4}{|c|}{$\begin{array}{l}\text { APOX ( } \mu \text { mol ascorbate oxidized } \\
\qquad \min ^{-1} \mathrm{~g}^{-1} \text { fresh wt.) }\end{array}$} \\
\hline & \multicolumn{2}{|c|}{ Root } & \multicolumn{2}{|c|}{ Shoot } & \multicolumn{2}{|c|}{ Root } & \multicolumn{2}{|c|}{ Shoot } & \multicolumn{2}{|c|}{ Root } & \multicolumn{2}{|c|}{ Shoot } \\
\hline $\begin{array}{l}\text { Days after } \\
\text { planting }\end{array}$ & 14 & 28 & 14 & 28 & 14 & 28 & 14 & 28 & 14 & 28 & 14 & 28 \\
\hline control & $13.44^{\mathrm{c}}$ & $23.36^{\mathrm{b}}$ & $6.30^{\mathrm{b}}$ & $17.22^{\mathrm{b}}$ & $30.81^{\mathrm{c}}$ & $72.24^{\mathrm{b}}$ & $108.08^{c}$ & $187.61^{\mathrm{a}}$ & $45.8^{\mathrm{b}}$ & $50.4^{\mathrm{b}}$ & $48.3^{\mathrm{b}}$ & $52.6^{\mathrm{b}}$ \\
\hline R.solani & $16.91^{\mathrm{b}}$ & $27.44^{\mathrm{a}}$ & $7.53^{\mathrm{b}}$ & $17.92^{\mathrm{b}}$ & $56.34^{\mathrm{b}}$ & $102.02^{\mathrm{a}}$ & $147.84^{b}$ & $193.86^{\mathrm{a}}$ & $49.8^{\mathrm{a}}$ & $73.6^{\mathrm{a}}$ & $50.4^{b}$ & $77.8^{\mathrm{a}}$ \\
\hline R.solanis + JA & $21.16^{\mathrm{a}}$ & $27.54^{\mathrm{a}}$ & $21.56^{\mathrm{a}}$ & $18.90^{\mathrm{a}}$ & $61.60^{\mathrm{a}}$ & $99.12^{\mathrm{a}}$ & $178.92^{\mathrm{a}}$ & $155.40^{b}$ & $51.3^{\mathrm{a}}$ & $53.4^{\mathrm{b}}$ & $80.4^{\mathrm{a}}$ & $79.6^{\mathrm{a}}$ \\
\hline LSD at $5 \%$ & 2.54 & 2.85 & 4.32 & 0.78 & 5.03 & 6.55 & 12.47 & 7.52 & 3.30 & 6.52 & 5.50 & 4.24 \\
\hline
\end{tabular}

Means within the same column with the same letter are not significantly different $(P \leq 5 \%)$

Present results showed that greater increase in the activity of antioxidation enzymes in JA-treated plants might be effective in scavenging mechanism to remove $\mathrm{H}_{2} \mathrm{O}_{2}$ produced in root and shoot under Rhizoctonia solani infection. On the other hand, accumulation of $\mathrm{H}_{2} \mathrm{O}_{2}$ in shoots of JA-treated plant could be related to the increased SOD activity and increase in $\mathrm{H}_{2} \mathrm{O}_{2}$-scavanging enzymes (CAT, POX and APOX).

\section{Changes in phenolic compounds and its related enzymes}

Result in Table (4) showed that total phenolic compounds markedly decreased in roots of bean plants (at two stages) infected by Rhizoctonia solani as compared with non infected control. Accumulation of phenolic compounds has been associated with disease resistance in a number of plant-pathogen interactions. A high level of phenolic compounds at the site of pathogen invasion can restrict or slow the growth of the pathogen.

$\mathrm{JA}$, when applied resulted in the highest total phenol. Increasing evidence indicates that JA increased the total phenolic contents in Hypericum perforatum cell suspension (Gadzouska et al., 2007). However, levels of certain phenolic acids greatly changed in roots of bean plants in response to pathogen inoculation and hormonal elicitor JA as compared with non infected control (Table 4). Ferulic acid and quercetin markedly decreased in root infected with Rhizoctonia solani, Gallic acid content also markedly decreased in roots of infected control and JA-treated plants. JA -treated plant recorded increase in cinnamic acid, ferulic acid, and quercetin which play an 
important role in plant resistance and defence against Rhizoctonia solani, initimately connected with $\mathrm{H}_{2} \mathrm{O}_{2}$ (Table 2).

Table 4. The contents of total phenolic acids and certain phenolic acids ( $\mathrm{mg} \mathrm{g}^{-1} \mathrm{fwt}$ ) in roots of bean plants (15 days after pathogen inoculation) treated with JA and grown in Rhizoctonia solani infested soil.

\begin{tabular}{|c|c|c|c|c|c|c|c|}
\hline \multirow{2}{*}{ Treatment } & \multirow{2}{*}{$\begin{array}{c}\text { No of } \\
\text { peaks }\end{array}$} & \multirow{2}{*}{$\begin{array}{c}\text { Total } \\
\text { phenolic } \\
\text { acids }\end{array}$} & $\begin{array}{c}\text { Cinnamic } \\
\text { acid }\end{array}$ & $\begin{array}{c}\text { Gallic } \\
\text { acid }\end{array}$ & $\begin{array}{c}\text { Ferulic } \\
\text { acid }\end{array}$ & Quercetin & coumarin \\
\cline { 5 - 8 } & & & & & & & \\
\hline $\begin{array}{c}\text { Non-infected } \\
\text { Control }\end{array}$ & 7 & 432.1 & $20 . .33$ & 21.97 & 32.44 & 11.4 & - \\
\hline $\begin{array}{c}\text { Infected control } \\
\text { (R.solani) }\end{array}$ & 10 & 325.6 & 28.94 & 11.25 & 33.86 & 26.39. & - \\
\hline R.solani + JA & 10 & 575.2 & 46.13 & 6.48 & 42.36 & 32.88 & 11.56 \\
\hline
\end{tabular}

These results agree with the induction of some phenolic compounds such as Gallic, Cinnamic, Ferulic, and Chlorogenic acids in chickpea from fungal attacks through induced resistance (Cherif et al., 2007).

Results in Table (5) showed that activities of polyphenol oxidase (PPO) and phenylalanine-ammonia lyase (PAL) significantly increased in both shoot and roots of bean plant in response to Rhizoctonia solani infection. Different studies showed that induced resistance, through the accumulation of various phenolic compounds and phytoalexins, as well as the activation of peroxidases, polyphenoloxidases, and key enzymes in phenylpropanoid and isoflavonoids pathways, may play a crucial role in the resistance of bean plants to pathogen attacks. PAL could directly affected accumulation of secondary toxic compounds, such as phytoalexins, which might be released in root exudates and on root segment surfaces from the infected plants to inhibit fungal spore germination and growth.

Chen et al. (2000) demonstrated the existence in cucumber of phenolic phytoalaxins, which might be produced through a PAL pathway. PAL may be involved in triggering phenylpropanoid pathway resulting in the release of toxic phtoalexins at the site of pathogen penetration.

POX activity is associated with disease résistance in plants and increases in host plants following pathogen infection. Plant POX has been reported to catalyze the last step in the biosynthesis of lignin and hydrogen peroxide Brausegem et al. (2001). POX and PPO are important in the defense mechanism against pathogen, through its role in the oxidation of phenolic compounds to quinones, causing increased antimicrobial activity. Therefore, it may be directly involved in halting pathogen development. 
Table 5. Activities of polyphenol oxidase (PPX), phenylalanine ammonia lyase (PAL) and peroxidase (POX) in roots and shoots of bean plants infected with Rhizoctonia solani (R.solani) and treated with JA.

\begin{tabular}{|c|c|c|c|c|c|c|c|c|c|c|c|c|}
\hline \multirow{2}{*}{$\begin{array}{l}\text { Treatment } \\
\text { Days after } \\
\text { planting }\end{array}$} & \multicolumn{4}{|c|}{ PPX(enzyme activity g-1 f wt. min-1) } & \multicolumn{4}{|c|}{ PAL (mM t-cinnamic acid g-1 f wt. h-1) } & \multicolumn{4}{|c|}{ POX(enzyme activityg- f wt. min-1) } \\
\hline & \multicolumn{2}{|c|}{ Root } & \multicolumn{2}{|c|}{ Shoot } & \multicolumn{2}{|c|}{ Root } & \multicolumn{2}{|c|}{ Shoot } & \multicolumn{2}{|c|}{ Root } & \multicolumn{2}{|c|}{ Shoot } \\
\hline control & $36.57^{c}$ & $49.81^{c}$ & $18.80^{c}$ & $42.21^{\mathrm{C}}$ & $13.65^{c}$ & $11.95^{\mathrm{c}}$ & $12.34^{\mathrm{b}}$ & $14.05^{\mathrm{c}}$ & $46.57^{\mathrm{b}}$ & $47.81^{\mathrm{b}}$ & $16.84^{\mathrm{C}}$ & $40.22^{b}$ \\
\hline R.solani & $50.32^{\mathrm{b}}$ & $55.03^{b}$ & $24.88^{b}$ & $56.83^{b}$ & $17.07^{b}$ & $20.06^{\mathrm{b}}$ & $14.08^{\mathrm{b}}$ & $18.35^{b}$ & $50.31^{a}$ & $50.92^{b}$ & $24.61^{b}$ & $51.83^{a}$ \\
\hline
\end{tabular}

Means within the same column with the same letter are not significantly different $(P \leq 5 \%)$

In the present study, application of JA as seed presowing treatment induced systemic resistance of bean plants against Rhizoctonia solani through induction of ROS, ceratin defence enzymes and some secondary metabolites.

\section{REFERENCES}

1. Abd El-kareem, F. 2007. Induced resistance in bean plants against root rot and Alternaria leaf spot disease using biotic and abiotic inducers under field conditions. J. Agric. Biol. Sci. 3 (6): 767-774.

2. Aebi, H. 1995. Catalase in vitro. Methods Enzymol. 105:121-126.

3. Brausegem, F., E. Vranova and J.F. Dat. 2001. The role of active oxygen species in plant signal transduction. Plant Sci. 1161: 405-414.

4. Chen, H., A. D. Jones and G. A. Howe. 2006. Constitutive activation of the jasmonate signaling pathway enhances the production of secondary metabolites in tomato. FEBS Letters. 580: 2540-2546.

5. Chen, C., R. R. Belanger, N. Benhamou and T. Paulitz. 2000. Defence enzymes induced in cucumber roots by treatment with plant growth promoting rhizobacteria (PGPR) and Pythium aphanidermatum . Physiol. Mol. Plant Pathol. 56: 13-23.

6. Cherif, M., A. Arfaoui and M. A. Rhaiem. 2007. Phenolic compounds and their role in bio-control and resistance of chickpea to fungal pathogenic attacks. Tunisia J. Plant Production. 2(1).

7. Gadzouska, S., A. Delaunnary, M. Spasenoski, S. Maury, C. Josef and D. Hagege. 2007. Jasmonic acid elicitation of Hypericum perforatum L. Cell suspensions and effects of the production of phenylpropanoids and naphthodianthrones. Plant Cell Tissue and Organ Culture. 89 (1): 1-13. 
8. Hallitschke, R. and I. T. Baldwin. 2005. Jasmonates and related compounds in plant-insect interaction. J. Plant Growth Regulation. 23: 238-245.

9. Huckelhoven, R. and K.H. Kogel. 2003. Reactive oxygen intermediates in plantmicrobe interactions: Who is who in powdery mildew resistance. Planta 216: 891902.

10. Jaiti, F., A. Dihazi, A. EL hadrami, M. EL hasni and I. EL hadrami. 2004. Effect of exogenous application of jasmonic acid on date palm defense reaction against Fusarium oxysporum f. sp. albedinis. Phytopathol. Mediterr. 43: 325-331.

11. Jiang, A.L., S. P. Tian and Y. Xu. 1984. Effect of controlled atmospheres with high$\mathrm{O}_{2}$ or high- $\mathrm{CO}_{2}$ concentrations on postharvest physiology and storability of "Napoleon" sweet cherry. J. Integrative Plant Biol. 44: 925-930.

12. Kim, H. J., F. Chen, X. Wang and N. C. Rajapakse. 2006. Effect of methyl jasmonate on secondary metabolites of sweet basil (Ocimum basilicum L.). J. Agricultural and Food Chemistry. 54: 2327-2332.

13. Luh, B. S. and B. Phithakpol. 1972. Characteristics of polyphenoloxidase related to browning in cling peaches. J. Food Sci. 37: 264-268.

14. Pieterse, C.M. and L. C. Van Loon. 1999. Salicylic acid-independent plant defense pathways. Trends in Plant Science. 4: 52-58.

15. Rao, M.V., G. Paliyath, and D. P. Ormrod. 1996. Ultraviolet-B-radiation and ozoneinduced biochemical changes in the antioxidant enzymes of Arabidopsis thaliana. Plant Physiol. 110:125-136.

16. Ross, W. W. and R. R. Sederoff. 1992. Phenylalanineammonia layse from loblolly pine: Purification of the enzyme and isolation of complementary DNA clones. Plant Physiology. 98: 380-386.

17. Segarra, G., O. Jauregui, E. Casanova and I. Trillas. 2006. Stimultaneous quantitative LC-ESI-MS/MS analysis of salicylic acid and jasmonic acid in crude extracts of Cucumis sativus under biotic stress. Phytochemistry. 67: 395-401.

18. Snedecor, G. M. and W. C. Cochran. 1969. Statistical method. $6^{\text {th }}$ Ed Iowa Univ. Press, Ames,Iowa, U.S.A.

19. Shimzu, N., N. Hosogi, G. S. Hyon, S. Jiang, K. Inoue and P. Park. 2006. Reactive oxygen species (ROS) generation and ROS induced lipid peroxidation are associated with plant membrane modifications in host cells in response to AK-toxin from Alternaria alternata Japanese pear pathotype. J. Gen Plant Pathol. 72: 6-15.

20. Silvana, B. D., M. G. Susana, P. B. Marria, and L. T. Maria. 2003. Behavior of antioxidant defense system in the adaptive response to salt stress in Helianthus annus L. Cells. Plant Growth Regul. 49:81 - 88. 
21. Swain, T. and W. E. Hillis. 1959. The phenolic constituents of Prunus domestica I. the quantitative analysis of phenolic constituents. J. Agric. \& Food Sci. 10: 63-68.

22. Ueeda, M., K. Masaharu and K. Nishi. 2006. Contribution of jasmonic acid to resistance against phytophthora blight in Capsicum annum cv. SCM 334. Physiol. Mol. Plant Pathol. 62.

23. Velikova, V., I. Yordanov and A. Edereva. 2000. Oxidative stress and some antioxidant systems in acid rain-treated bean plants. Protective role of exogenous polyamines. Plant Sci. 151: 59-66.

24. Yehia, A., G. Mahmoud, R. M. Gaafar and H. M. Mubarak. 2008. Genetic diversity among Nile delta isolates of Rhizoctonia solani kuhn based on pathogenicity, compatibility, isozyme analysis and total protein pattern. Turk. J. Bot. 31: 19-29.

25. Yingsanga, P., V. Sriloang, S. Kanalyanarat, S. Noichinda, and W. B. McGlasson. 2008. Relation between browning and related enzymes (PAL, PPO and POD) rambutan fruit (Nephelium lappaceum Linn.) cvs. Rongrien and see-chompoo. Postharvest Biology and Technology. 50: 164-168. 
استحثاث مقاومة نباتات الفاصوليا لمرض عفن الجذور المتسبب بفطر الرايزوكتونيا سولانى باستخدام حمض الجاسمونيك

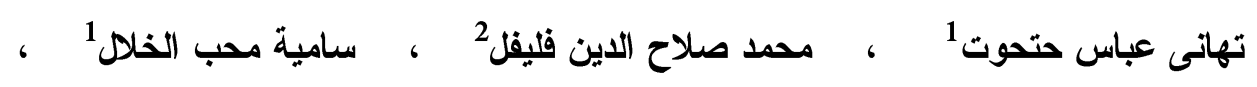
هلى حسن أبو غالية 1 رباب عبد الحي جاد 1

$$
\begin{aligned}
& \text { ا ـ قسم النبات- كلية البنات للآداب و العلوم و التربية- جامعة عين شعس - القاهرة } \\
& \text { r r معز بحوث أمراض النبات - مركز البحوث الزراعية - الجبيزة }
\end{aligned}
$$

يهدف هذا البحث إلى دراسة تأثير حضض الجاسمونيك المستحث للنمو على زيادة مقاومه

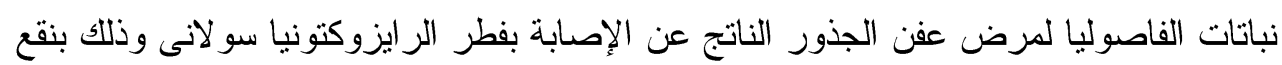

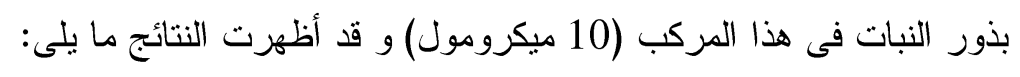

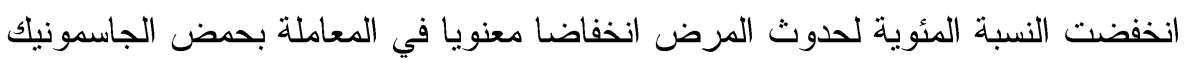

$$
\text { تحت ظروف العدوى الصناعية. }
$$

زاد محتوى جذور و سيقان النباتات من مسببات الأكسدة من نو اتج الأكسجين الحرة و خاصده

فوق أكسيد الهيدروجين في النباتات المصابة بفطر الريزوكتونيا بالمقارنة بمثيلتها الغير مصنابه.

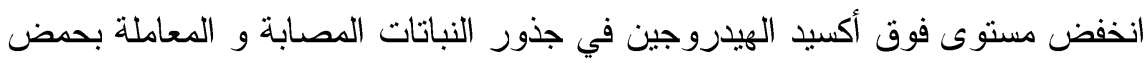

الجاسمونيك بعد تتميتها لمدة 14 ، 28 يوم و قد انخفض أيضا معدل أكسدة الدهون (peroxidation) فى هذه النباتات بمقارنتها بالنباتات المصابة بفطر الريزوكتونيا.

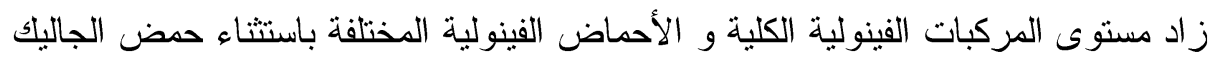

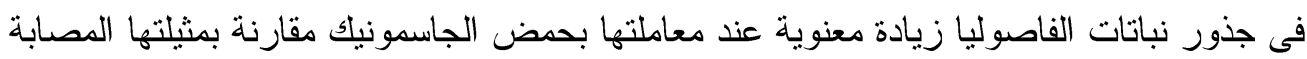
و الغير مصابة بفطر الريزوكتونيا. أما حمض الكومارين فقد استحث فقط في النباتات المعاملة بالهزمون.

زاد نشاط إنزيمات البولي فينول اوكسيديز و البيروكسيديز و الفينل ألانين امونيا لاييز فى

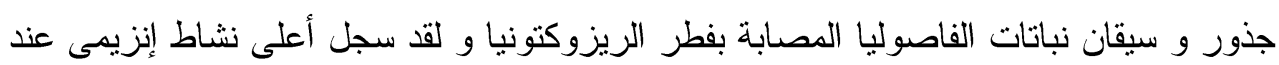
معاملة نلك النباتات بهرمون حمض الجاسمونيك. لبان. 